\title{
Analysis of the Marketing Strategies of Luxury Cars in China_Porsche as an Example
}

\author{
Jingchun Guo
}

\section{The University of Vermont}

Email:985880664@qq.com

\begin{abstract}
The paper firstly introduces the current development status and possible development trend of Chinese luxury car market. In the following of the paper, the marketing strategy of Porsche car in China is researched, and the reasonable suggestions are proposed to improve the marketing ability after making the influencing strategy selection via 4P theory.
\end{abstract}

Keywords: Luxury car, Porsche, Chinese market, $4 P$ theory, Marketing strategies

\section{INTRODUCTION}

Along with the rapid growth of Chinese car ownership, constant improvement of people's living standard and consumption standard, increasingly decrease of car price and diversification of car financial service, Chinese car market enters into the channel of rapid development, and becomes the global largest car consumption market with huge development potential. The international car giants land in Chinese market, the war flame is spread from the ordinary household car to the high-end luxury car. According to the related statistics, the sales amount of luxury car accounted for $30 \%$ in Chinese car consumption market in 2018.

In Chinese luxury sports car market with numerous audiences, the consumer's consumption habits are complicated and diversified from different ages, different careers and other aspects; therefore, analyzing the group feature, consumption psychology and preference of the targeted consumers of Porsche brand becomes the key for the marketing of Porsche car business marketing.

\section{2、ABOUT PORSCHE}

\subsection{History}

\subsubsection{Origin}

Ferdinand Porsche founded the company called "Dr. Ing. h. c. F. Porsche GmbH" in 1931, with main offices at Kronenstrasse 24 in the centre of Stuttgart. Initially, the company offered motor vehicle development work and consulting, but did not build any cars under its own name. One of the first assignments the new company received was from the German government to design a car for the people, that is a "Volkswagen". This resulted in the Volkswagen Beetle, one of the most successful car designs of all time. The Porsche 64 was developed in 1939 using many components from the Beetle.

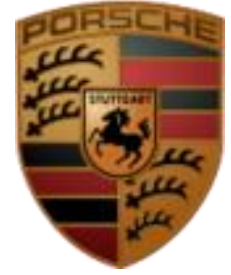

Porsche logo

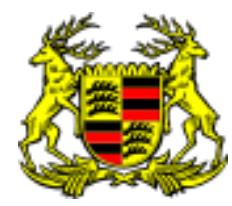

Weimar-era Württemberg

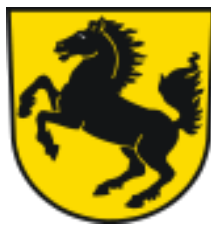

Coat of arms of Stuttgart

Figure 1 Logos of Porsche, Württemberg and Stuttgart 
Porsche's company logo was based on the coat of arms of the Free People's State of Württemberg of former Weimar Germany, which had Stuttgart as its capital. (The same arms were used by Württemberg-Hohenzollern from 1945-1952, while Stuttgart during these years was the capital of adjacent Württemberg-Baden.) The arms of Stuttgart was placed in the middle as an inescutcheon, since the cars were made in Stuttgart. The heraldic symbols were combined with the texts "Porsche" and "Stuttgart", which shows that it is not a coat of arms since heraldic achievements never spell out the name of the armiger nor the armigers home town in the shield[1].

\subsubsection{Relationship with Volkswagen}

The company has always had a close relationship with, initially, the Volkswagen (VW) marque, and later, the Volkswagen Group (which also owns Audi AG), because the first Volkswagen Beetle was designed by Ferdinand Porsche.

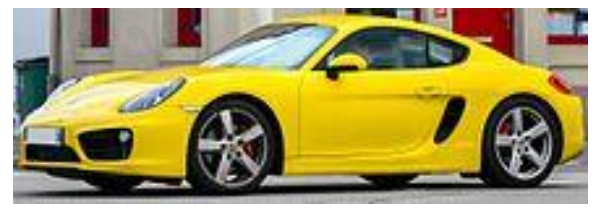

Porsche Cayman

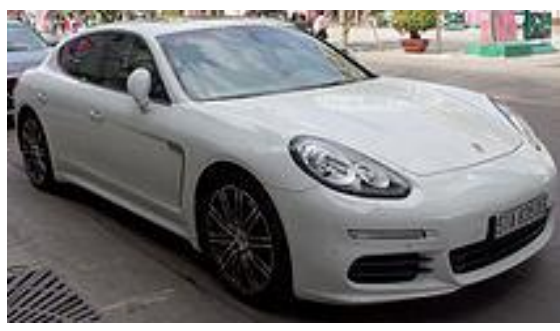

Porsche Panamera

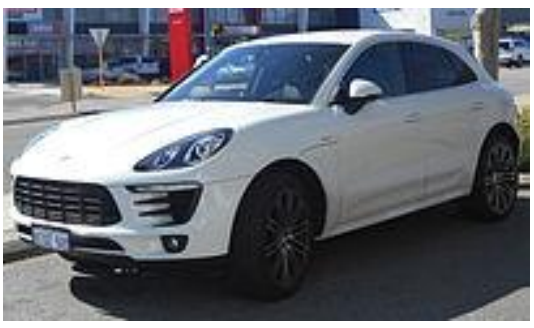

Porsche Macan
The two companies collaborated in 1969 to make the VW-Porsche 914 and 914-6, whereby the 914-6 had a Porsche engine, and the 914 had a Volkswagen engine. Further collaboration in 1976 resulted in the Porsche 912E (USA only) and the Porsche 924, which used many Audi components, and was built at Audi's Neckarsulm factory. Porsche 944s were also built there, although they used far fewer Volkswagen components. The Cayenne, introduced in 2002, shares its chassis with the Volkswagen Touareg and the Audi Q7, which is built at the Volkswagen Group factory in Bratislava, Slovakia.

\subsubsection{Models}

The current Porsche model range includes sports cars from the Boxster roadster to their most famous product, the 911. The Cayman is a coupé otherwise similar to the Boxster. The Cayenne is Porsche's mid-size luxury sport utility vehicle (SUV). A high performance luxury saloon/sedan, the Panamera, was launched in 2009.

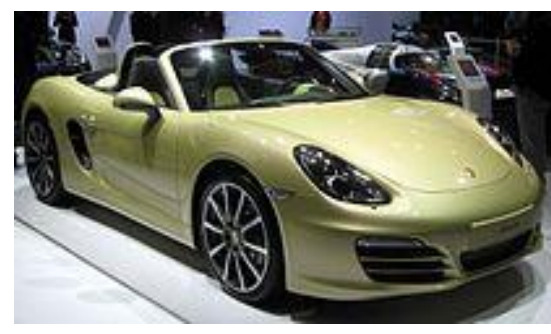

Porsche Boxster

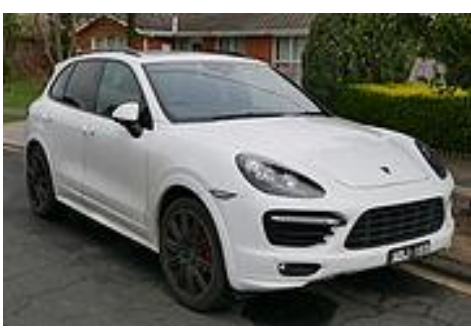

Porsche Cayenne

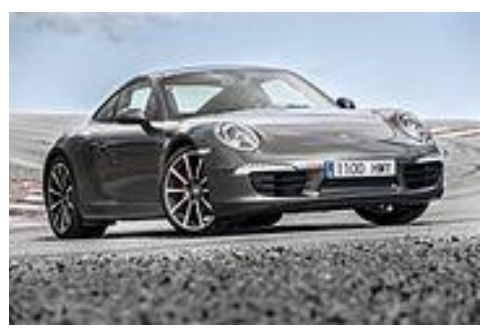

Porsche 911

Figure 2 Customer Models

\subsubsection{Motorsport}

Porsche is the most successful brand in motorsport, scoring a total of more than 28,000 victories, including a record 16 outright wins at the 24 Hours of Le Mans. Porsche is currently the world's largest race car manufacturer. In 2006, Porsche built 195 race cars for various international motor sports events. In 2007, 
Porsche was expected to construct no fewer than 275 dedicated race cars, and they made it.

\section{2 The Present Situation of Porsche in Chinese Market}

After the start of 2020 many brands have also announced some of their specific sales for 2019, but there are some brands that have not been announced, such as Porsche. And just recently they have finally announced their statements with relative relief, the reason for this is because their car sales performance is really very well.

In the brand's announcement of their 2019 results, it is clear to see that in 2019 Porsche delivered a total of 86,752 new models in China, up $8 \%$ year-on-year and accounting for $31 \%$ of the brand's sales of 280,800 units. This can be seen that the contribution of the Chinese market is huge for them, so that they are also focusing their attention mainly on the Chinese market. Although it is said that for special reasons, so that in February this year all brands around the world fell more significantly. So Porsche's decline is also quite exaggerated.

The whole increase in performance is also very good, according to the total number of 280,800 units of the Porsche brand worldwide, the two models accounted for more than $68 \%$ of sales, which can also be seen, these two models are the real main models The reason why many brands are launching SUVs is that they should be looking at the sharp performance of the Porsche brand in this market.

German luxury carmaker Porsche AG is consolidating its position in China as it expects sales to hit a new high in the world's largest car market. In 2015,Porsche sold 58,000 cars in China, making the country its largest market worldwide. Porsche is improving customer satisfaction as it makes further forays into the Chinese market. It has been steadily expanding its dealer network in the country. To date, there are 94 dealerships in China, most of them in tier-one and tier-two cities, accounting for 80 percent of its sales.

Porsche has built in Shanghai a training center, the largest of its kind in the world, and an experience center will begin operation in 2017. They will allow Chinese consumers to better experience the authentic Porsche brand.

\section{BASIC FEATURES OF PORSCHE CONSUMERS}

\subsection{Features in Age and Sex}

The consumption group for the Porsche consumers is similar to that of other luxury car, the male accounts for $72 \%$, and the female accounts for $28 \%$. Although the number is not a half in the family car as $51.8 \%$, it can not be ignored for the female consumers as the main consumption group of Porsche. The average age of the consumer is $30-39$.

\subsection{Features in Occupational and Family Background}

The main consumers of Porsche car are private enterprise owners, accounting for $57 \%$ of the consumption occupations, then is the enterprise manager accounting for $28 \%$. The second-generation rich consumers for the loved car relying on the wealth accumulated by the elder only account for $10 \%$.

Porsche has always produced expensive, but powerful coupe, this simple business model has made the company one of the world's top luxury goods sellers, the brand is highly respected.

As with any car, the "Porsche" logo represents status, and its consumer base is not large, but definitely the most car-savvy. According to Porsche China's statistics for the 2004/2005 fiscal year, which ended at the end of July, Porsche sales in China increased by 109 percent. Orders for new cars from China are already lined up until next May, and Porsche is therefore expecting to triple its sales in China in the next fiscal year. It has to be admitted that China's newest group of luxury cars will have the world's attention.

\subsection{Investment Situation in Car Purchasing}

Most fund for the Porsche consumers are disposed by themselves, the investment ratio via free money accounts for $45 \%$, joint property between the husband and wife accounts for $35 \%$. It shall be noted that the payment way for the Porsche consumers is different from that in the ordinary luxury car, they prefer the full payment rather than the loan of low-interest rate financial service from the car manufacturer. The ratio reaches 57\%, thus reflecting that the Porsche consumers are more personalized, they care more about themselves rather than considering the surrounding family[2].

\section{PORSCHE'S SELECTION OF MARKETING STRATEGIES UNDER 4P THEORY IN CHINA}

\subsection{Product Strategy}

The product strategy shall be the central position in the Chinese marketing strategy system of Porsche brand. Although the Porsche car can be defined as the luxury car, the usefulness is a key factor to decide the market performance.[3] For the product strategy, the Porsche shall continue to adhere the main market breakthrough of Macan, and explore the specific market combined with Cayenne and Panamera and other cars. The good 
performance of Porsche car in Chinese market is connected with the luxury quality of holographic product directly. Along with the constant improvement of Chinese people's safety awareness and quality awareness, the Porsche shall pay attention to the improvement of car performance in the process to research the new car.

\subsection{Price Strategy}

Chinese market has become a watching market among the luxury car brands in the world, the price strategy shall be adjusted for the better marketing of Porsche brand in Chinese market. Moreover, the car finance and replacement are the common ways in current domestic car sales[4], the optimization of pricing strategy of Porsche brand in China can refer to these two kinds of ways. Equipping with more price advantages can help the Porsche to be leading in the fierce luxury car market competition.

\subsection{Promotion Strategy}

It is common to decrease the price of luxury car in Chinese market, the major luxury car manufacturers make the promotion activity to the largest degree to attract more attention in order to get the better market performance.[5] The exhibition marketing plays an important part in the domestic luxury car market sales, the sales strategy of Porsche brand in Chinese market shall fully note and suitably launch the promotional activity for Changchun car exhibition, Beijing car exhibition, Shanghai car exhibition and other car exhibitions. In the retail end, the actually responsible enterprise of Porsche in China shall coordinate with the dealers in the region to select the actual promotional strategy, guarantee the gradual release of the purchase in Chinese market via the phased and batched promotional strategy, the practice can reach the promotion purpose while not have the negative impact on the value of Porsche brand.

\section{5、 CONCLUSION}

In China with fierce competition, the international car giants enter China, the competition of luxury car market is fiercer, the consumer's demand is personalized increasingly. Many car types, higher cost performance, more humanized service and good consumer experience are becoming the development trend of luxury car brand. In addition to the traditional marketing means, Porsche Group shall also pay attention to the consumer's experience and publicity, achieve the development of product and service, consistence of brand and image, truly improve the brand marketing effect and constantly improve the brand value. Although there is a long way to go, we still expect Porsche group brand can create the brilliance in other segmented market in the near future, and become the leader of the luxury car brand in China.

\section{REFERENCES}

[1] Anas Bin Aqeel. Development of Visual Aspect of Porsche Brand using CAD Technology[J]. Procedia Technology,2015,20:

[2] Wilson, Amy. U.S. Porsche dealers to receive more Macans[J]. Automotive News,2015,89(6667):

[3] Lester, R., 2007. Porsche principle. Strategic Direction, 23(8).

[4] Baur, D., 2015. Case Study: Porsche versus Volkswagen. SSRN Electronic Journal.

[5] Bognanno, M. and Melero, E., 2015. Promotion Signals, Experience, and Education. Journal of Economics \& Management Strategy, 25(1), pp.111-132. 